Nat. Hazards Earth Syst. Sci. Discuss., https://doi.org/10.5194/nhess-2018-194

Manuscript under review for journal Nat. Hazards Earth Syst. Sci.

Discussion started: 5 September 2018

(c) Author(s) 2018. CC BY 4.0 License.

\title{
Monthly and seasonal rainfall (1963-2017) for a typhoon-influenced area in a Chinese karst basin
}

\author{
Chongxun Mo ${ }^{1,2,3}$, Yuli Ruan ${ }^{1,2,3,{ }^{*}}$, Jiaqi $\mathrm{He}^{1,2,3}$, Guikai Sun ${ }^{1,2,3}$, Juliang $\mathrm{Jin}^{4}$
}

${ }^{1}$ College of architecture and civil engineering Guangxi University, Nanning, China

$5 \quad{ }^{2}$ Key Laboratory of Disaster Prevention and structural Safety of Ministry of Education, Nanning, China

${ }^{3}$ Guangxi Key Laboratories of Disaster Prevention and Engineering Safety, Nanning, China

${ }^{4}$ School of Civil Engineering, Hefei University of Technology, Hefei 230009, China

Correspondence to: Yuli Ruan (yuliruan777@163.com)

Abstract. Under the dual influence of global warming and typhoon weather, the characteristics of monthly and seasonal

10 rainfall become more complicated and extreme, leading to more frequent rainfall and flood disasters. The objective of this study is to propose a framework for analysing the characteristics of rainfall and its correlation with typhoons. The proposed framework consists of an analysis of inner-annual distribution, inter-annual variation as well as correlation between rainfall and typhoons. Especially, a DVM method is proposed to compute the rationality and reliability of the abrupt change time analysis. Finally, the proposed framework was successfully implemented using a 55-year time series (1963-2017) of rainfall

15 data recorded by 12 rain gauges in Chengbi River Basin (South China).The results are as follows. (1) The relative variability of monthly rainfall is relatively large (above $30 \%$ ), and the rainfall tends to be centralized, and is mainly concentrated in July. (2) The monthly average rainfall is relatively stable, the seasonal rainfall decreases in spring and summer, while increases in autumn and winter. The abrupt change occurred during 1980s-1990s. The main periods of rainfall in summer and winter are shorter than those in spring and autumn. (3) The typhoon-caused rain is the main factor affecting the summer and autumn rainfall while the number of typhoons has the least influence. It is suggested that the impact of typhoon should be taken into consideration in the modelling of spatial and temporal evolution of hazardous rainfall evens and their social hazard assessment for a typhoon-influenced area .Besides, preventive measures should be strengthened for flood and waterlogging disasters and that the reservoir should be operated at different FLWLs during different flood sub seasons in Chengbi River Basin.

\section{Introduction}

The analysis of hydro meteorological elements has been a popular and frontier issue in recent years. Rainfall is an important factor affecting natural disasters, such as floods and droughts. With global climate change and the intensification of human activities, the characteristics of rainfall are more complex, and they have attracted the attentions of scholars all over the world. Many studies have shown that a study of rainfall characteristics mainly starts from two aspects: inner-annual distribution and inter-annual variation. 
Nat. Hazards Earth Syst. Sci. Discuss., https://doi.org/10.5194/nhess-2018-194

Manuscript under review for journal Nat. Hazards Earth Syst. Sci.

Discussion started: 5 September 2018

(c) Author(s) 2018. CC BY 4.0 License.
Natural Hazards

and Earth System

Sciences

Discussions

(c) (i)

Several indices can be applied to study the inner-annual distribution of rainfall, such as precipitation concentration degree (PCD), precipitation concentration period (PCP) and non-uniformity index. For example, the non-uniformity index and regulation coefficient were applied to analyse the annual distribution characteristics of rainfall in Henan province, China (Wang et al., 2007). Additionally, PCD, PCP and inhomogeneous distribution coefficient were analysed, and the annual

5 distribution characteristics of rainfall were studied. The results showed that the distributions of heavy rain, rainstorms and erosive rainfall events were uneven (Gao et al., 2017). Many studies have shown that trend, abrupt change time and period can correctly represent the inter-annual variation characteristics of rainfall to some degree. Recently, some methods have been suggested for examining the trends of annual, seasonal and monthly rainfall (Luković et al.,2014). Additionally, trends of daily rainfall characteristics, including intensity, duration and frequency, were analysed in Finland (Irannezhad et al.,

10 2016). In Japan, researchers were interested both in the trends of rainfall and their relationship to moisture variations and topographic convergence (Iwasaki, 2015). For China, the trends in precipitation can vary from time to time and place to place (e.g.Zhang et al., 2007; Gao et al., 2012; Zeng et al.,2013; Wu et al.,2016). In addition, the abrupt change time (e.g.Tarhule and Woo, 2015; Zhang et al.,2009; Guerreiro et al.,2014; Peng et al.,2016) and period ( Yu et al.,2012; Iqbal and Ali,2013) of rainfall are also the focus of contemporary studies.

15 The rainfall mechanism in Guangxi Zhuang Autonomous Region (Guangxi) are :(1) cyclonic (typhoon) activities, such as typhoon rain during the summer and autumn;(2) terrain blocking, such as orographic rain;(3) convective motion, such as thunderstorm in summer afternoon;(4) frontal activities, such as mould rains at the turn of spring and summer. Cyclonic activities and topographic barriers are the core mechanism of rainfall change in Guangxi.This study mainly focuses on typhoon. On one hand, Guangxi is located in the low latitudes of China; the rainfall is influenced by geographical location

20 and monsoon circulation, especially typhoon, which frequently causes drought and waterlogging disasters. Therefore, some studies have focused on the characteristics of tropical cyclones (typhoons) and their influence. In 2005, regular data from 1960 to 1999 was used to study the intensity variation, maintaining time and disappeared-location characteristics of tropical cyclones for Guangxi region (Chen et al., 2005). Additionally, some researchers were interested in the statistical characteristics of typhoon-heavy rainfall in Beibu Gulf Area of Guangxi (He et al.,2007). In 2014, the CMA best track data from 1953 to 2012 were used to study the spatial-temporal distribution and inter-annual variation in tropical cyclones, and the results showed that frequency and maximum intensity of the TCs were decreasing, while the average intensity was increasing (Zhang et al.,2014). From these studies, we know that from 1960 to 2010, there were 60 occurrences of rainstorms with large ranges in this region, which brought serious economic losses and posed a threat to the life, health and safety of the local inhabitants. Additionally, Guangxi is located in tropical monsoon region, which is influenced by the alternation of

30 winter and summer monsoons and a complex geographical environment, so severe drought disasters occur frequently. For example, there were 3 large drought disasters in Guangxi from 1998 to 2009 (Dong, 2014). This is also a proof that the intensity and ratio of extreme events caused by global climate change have increased. On the other hand, most of the basins in Guangxi are karst basins with shallow soil layers and steep hills. Natural disasters, such as soil erosion and landslides, are 
Nat. Hazards Earth Syst. Sci. Discuss., https://doi.org/10.5194/nhess-2018-194

Manuscript under review for journal Nat. Hazards Earth Syst. Sci.

Discussion started: 5 September 2018

(c) Author(s) 2018. CC BY 4.0 License.
Natural Hazards

and Earth System

Sciences

Discussions

(c) (i)

closely related to rainfall on monthly and seasonal scales. Therefore, it is necessary and urgent to study the characteristics of monthly and seasonal rainfall.

In summary, rainfall is an important factor that leads to occurrence of floods, droughts and other natural disasters, especially under the background of global warming. Frequency of extreme weather events will likely continue to increase, so an

5 analysis of the characteristics of rainfall is vital to take appropriate technical means to prevent the disasters caused by extreme rainfall. Rainfall is affected by geographical location and monsoon circulation, especially typhoon in Guangxi, and therefore characteristics of rainfall will be more complex than those in other places. However, there are few studies about the characteristics of rainfall and its relationship to typhoons in Guangxi karst basin at present. In this study, we will try to answer two questions: first, how are the characteristics of monthly and seasonal rainfall in the context of climate change?

10 And second, whether the changes of rainfall have some relationship with typhoons or how typhoons affect the rainfall? The objectives are as follows: (1) analyse the inter-annual distribution of rainfall with the help of relative variability, PCD and PCP indices; (2) study the inter-annual variation characteristics (trends, abrupt change time and period) of rainfall by using Mann-Kendall method, hydrologic variation diagnosis system, and wavelet analysis; and (3) analyse the relationship between rainfall and typhoons using Pearson correlation coefficients and Grey relational analysis. The innovations of the

15 study are: (1) it is the first study on monthly and seasonal rainfall characteristics and their correlations with typhoon of a karst-typhoon doubly affected area in southwest China; (2) in addition, in the analysis of abrupt change time, we put forward a DVM method. This method can provide a more reasonable and reliable analysis of the initial determined abrupt change time, making the study more accurate and credible.

\section{Study area and data}

20 Chengbi River Basin belongs to Xijiang River system, and the river originates from Qinglong Mountain in the northern area of Lingyun County, Baise City, Guangxi. The total area of this basin is $2087 \mathrm{~km}^{2}$, the average elevation is $650 \mathrm{~m}$, the shape of the basin is similar to a rectangle, and the terrain is high in the northwest and low to the southeast. The basin covers typical karst limestone landforms, including an underground river, a falling water cave, and hilly landforms, high mountains and high vegetation coverage. The basin is located in subtropical monsoon climate zone, and therefore the climate is mild

25 and the rainfall is abundant. The annual rainfall distribution is uneven, and the average annual rainfall reaches $1560 \mathrm{~mm}$. The climate is abnormal, with gales and hail weather in April and high temperature, heavy rain and strong wind weather patterns from July to September, which very easily form disastrous floods. In this study, 12 monitoring stations are used: Ba Shou (BS) station, Bai Lian (BL) station, Xia Tang (XT) station, Lin He (LH) station, Ping Tang (PT) station, Hao Kun (HK) station, Nong Tang (NT) station, Chao Li (CL) station, Xia Jia (XJ) station, Lin Yun (LY) station, Dong He (DH) station and

30 Jie Fu (JF) station (Figure 1). The 55-year (1963-2017) monthly and season rainfall data from each station are provided by the ChengBi River Reservoir administration, and the typhoon data (the number of typhoons per year, the typhoon maintaining time and the maximum typhoon wind speed) can be download from http://typhoon.nmc.cn. Then, following 
Nat. Hazards Earth Syst. Sci. Discuss., https://doi.org/10.5194/nhess-2018-194

Manuscript under review for journal Nat. Hazards Earth Syst. Sci.

Discussion started: 5 September 2018

(C) Author(s) 2018. CC BY 4.0 License.
Natural Hazards

and Earth System

Sciences

Discussions

(c) $\underset{\text { BY }}{\text { (i) }}$

methods are adopted to interpolate and extend the monitoring station with data missing: (1) The mean value of the adjacent data have been used to interpolate the monitoring stations with less data missing .(2) For the monitoring stations with more data missing, firstly, Ba Shou station has been used as reference station then use simple linear regression model (R2 $>0.95$ ) to interpolate the data. The rationality and feasibility of the above methods have been verified by (Zhang et al., 2015).

5 Finally the mean areal rainfall calculated by Thiessen polygon method is applied to this study.

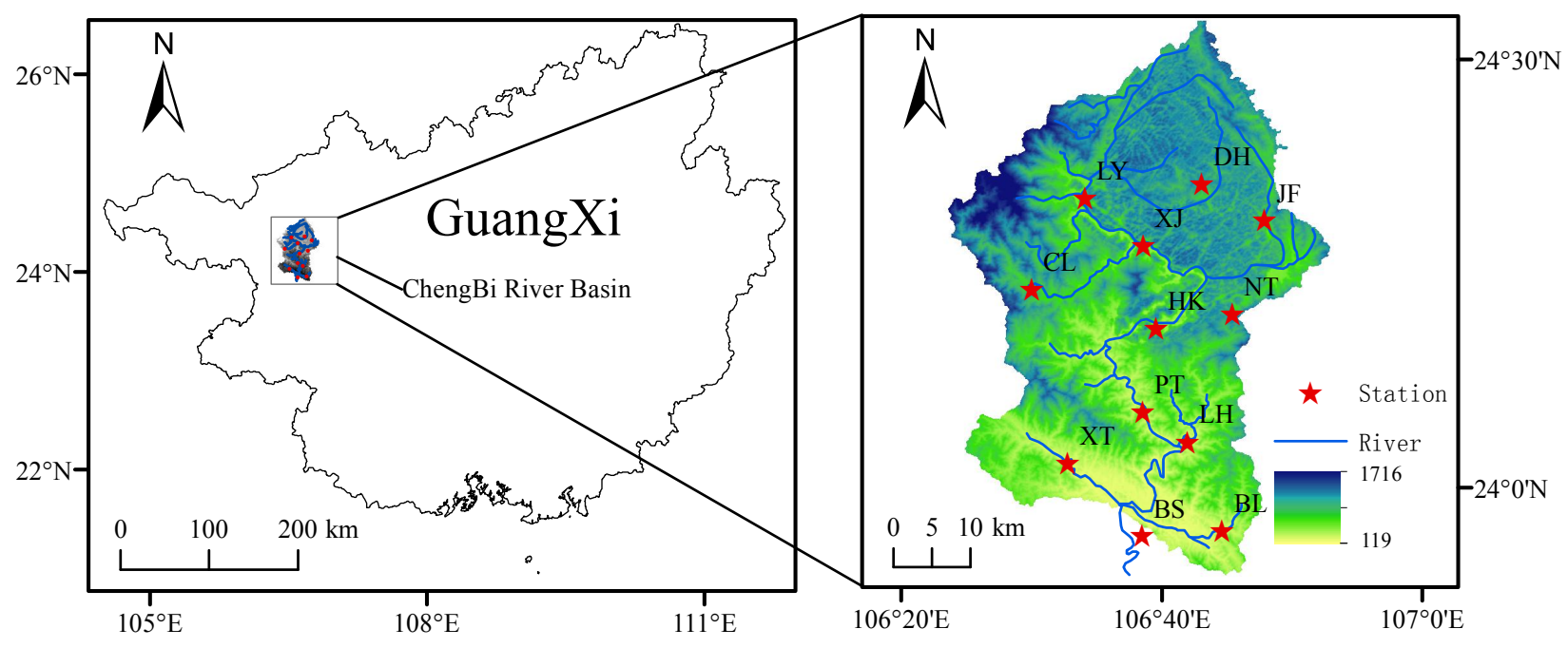

Fig. 1 The location of Chengbi River Basin and the distribution of the rainfall stations, and the representative rainfall stations are shown as red stars

\section{Methods}

\subsection{Methods for inner-annual distribution analysis}

The inner-annual distribution characteristics of rainfall mainly include rainfall stability and concentration. The characteristics of rainfall stability can be reflected by its average relative variability, where the greater the average relative variation in rainfall, the more unstable the rainfall is (Conrad,1941; Sun,1986).

PCD and PCP are two important indexes that represent the inner-annual distribution of rainfall. The rainfall of each month is

15 taken as a vector, length of the vector is the size of the rainfall, while direction of the vector is the time of the rainfall. From January to December, the azimuth angle of each month is $\theta=0^{\circ}, \theta=30^{\circ}, \theta=60^{\circ}, \cdots \theta=330^{\circ}$, and the monthly 
Nat. Hazards Earth Syst. Sci. Discuss., https://doi.org/10.5194/nhess-2018-194

Manuscript under review for journal Nat. Hazards Earth Syst. Sci.

Discussion started: 5 September 2018

(c) Author(s) 2018. CC BY 4.0 License.

(c) (i)
Natural Hazards

and Earth System

Sciences

Discussions

rainfall is divided into two components: $R_{x}$ and $R_{y}$. The calculation formula is as follows (Zhang and Qian, 2003):

$$
\begin{aligned}
& R_{x}=\sum_{i=1}^{12} R(i) \operatorname{Cos} \theta_{i} \\
& R_{y}=\sum_{i=1}^{12} R(i) \operatorname{Sin} \theta_{i}
\end{aligned}
$$

Then, the precipitation $R_{x}$ and $R_{y}$ can be synthesized as $R$, and $R=\sqrt{\left(R_{x}^{2}+R_{y}^{2}\right)}$. The PCD and PCP can be calculated as follows:

$$
\begin{aligned}
& P C D=\frac{R}{\sum_{i=1}^{12} R(i)} \\
& P C P=\arctan \left(\frac{R_{y}}{R_{x}}\right)
\end{aligned}
$$

\subsection{Methods for inter-annual variation analysis}

Trend, abrupt change time and period are often used to analyse the inter-annual variation characteristics. The trend and abrupt change time analysis are mainly based on nonparametric statistical methods. Many studies have shown that the existence of autocorrelation will have a great influence on the results of nonparametric statistical methods, so before using nonparametric statistical methods to analyse the trend and abrupt change time, the series should be first tested with autocorrelation. If autocorrelation exists within the data series, it needs to be eliminated. Therefore, in this study, we tested and eliminated the autocorrelation before performing the trend and abrupt change time analysis by using the lag- 1 of the ACF (denoted as ACF1) and "Pre-Whitening" methods (Scorch ,1999).

\subsubsection{Trend analysis methods}

15 Linear regression (Wei, 1999) and Sen+Mann-Kendall methods were applied to analyse the trend of the rainfall series in Chengbi River Basin. Linear regression analysis is an important method that analyse trend. This method is simple and easy to operate. However, it requires the samples to be normally distributed and susceptible to noise interference. Sen Trend degree is a median of the calculated series, and it can reduce the noise interference well, but it cannot analyse the significance of trend. Mann-Kendall method is not sensitive to sequence distribution and is not sensitive to outliers.

20 Therefore, this method can be used to test the significance of trend. The rainfall data from 1963 to 2017 in Chengbi River Basin have some abnormal values due to climate change and human activity, and the distribution characteristics have not 
Nat. Hazards Earth Syst. Sci. Discuss., https://doi.org/10.5194/nhess-2018-194

Manuscript under review for journal Nat. Hazards Earth Syst. Sci.

Discussion started: 5 September 2018

(C) Author(s) 2018. CC BY 4.0 License.

(c) (i)

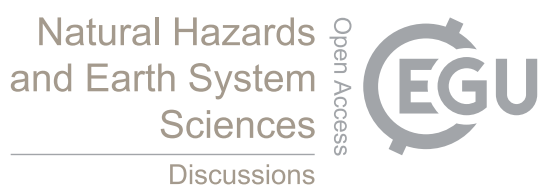

been determined yet. Therefore, the combination of these two methods (Sen+Mann-Kendall) can enhance the noise resistance of the method and improve the accuracy of results.

Sen+Mann-Kendall

The formula for calculating the Sen Trend is as follows (Sen, 1968):

$5 \quad \beta=\operatorname{Median}\left(\frac{x_{j}-x_{i}}{j-i}\right), \forall j>i$,

where $\beta$ is the trend degree, which can be used to judge trend of rainfall. When $\beta>0$, the rainfall tends to increase, and when $\beta<0$ the rainfall tends to decrease.

The Mann-Kendall test statistic S can be calculated as follows (Mann, 1945; Kendall, 1975):

$S=\sum_{i=1}^{n-1} \sum_{j=i+1}^{n} \operatorname{sgn}\left(x_{j}-x_{i}\right)$

$10 \operatorname{sgn}\left(x_{j}-x_{i}\right)=\left\{\begin{array}{l}+1, \text { if } x_{j}>x_{i} \\ 0, \text { if } x_{j}=x_{i} \\ -1, \text { if } x_{j}<x_{i}\end{array}\right.$

where $n$ is the number of samples and $x_{i}$ and $x_{j}$ are the data values in time series $i$ and $j(j>i)$, respectively.

It is generally believed that when the number of samples is greater than 10, the statistic $S$ obeys a normal distribution, so the test statistic $Z$ is used to test trend. The $Z$ value can be calculated as follows:

$\mathrm{Z}=\left\{\begin{array}{l}\frac{S-1}{\sqrt{\operatorname{VAR}(S)}}, S>0 \\ 0, \quad S=0 \\ \frac{S+1}{\sqrt{\operatorname{VAR}(S)}}, S<0\end{array}\right.$,

$\operatorname{VAR}(S)=\frac{n(n-1)(2 n+5)-\sum_{i=1}^{m} t_{i}\left(t_{i}-1\right)\left(2 t_{i}+5\right)}{18}$

where $n$ is the number of data points, $m$ is the number of tied groups and $t_{i}$ denotes the number of ties of extent $i$. 
Nat. Hazards Earth Syst. Sci. Discuss., https://doi.org/10.5194/nhess-2018-194

Manuscript under review for journal Nat. Hazards Earth Syst. Sci.

Discussion started: 5 September 2018

(c) Author(s) 2018. CC BY 4.0 License.

(c) (i)

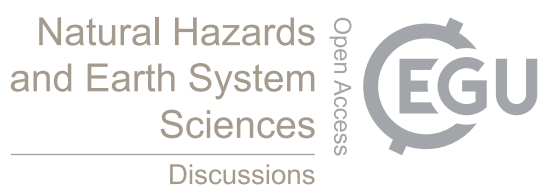

\section{2. 2 Abrupt change time analysis methods}

In this study, abrupt change time analysis can be divided into three steps:(1) preliminary identification of abrupt change time using Mann-Kendall mutation detection method; (2) a hydrological variation diagnosis system combined with several common methods (sequential clustering, sliding F, Lee-Heghinan, sliding T, cumulative anomaly inspection, and the sliding rank sum test) for comprehensive detection to determine the called exact abrupt change time; and (3) the degree of variability method (DVM) was proposed to analyse the rationality and reliability of results. This study gives only a brief introduction to the Mann-Kendall and DVM method, and the specific steps of other methods can be found in the relevant literature (Lei et al.,2007; Heghinian, 1977).

\section{Mann-Kendall Mutation Detection method}

10 Assume that the original rainfall series is $y_{1}, y_{2}, \ldots, y_{n}$ and $m_{i}$ is the cumulative number when the sample $y_{i}$ is greater than $y_{j}(1 \leq j \leq i)$, ; the statistic is defined as (Zhou et al., 2011;Li et al.,2012):

$d k=\sum_{i=1}^{k} m i,(2 \leq k \leq n)$

The mean value and the variance of $d k$ are:

$$
E(d k)=k(k-1) / 4 ; \operatorname{var}(d k)=k(k-1)(2 k+5) / 72
$$

15 Standardization of $d k$ is given by:

$$
U F(k)=\frac{d k-E(d k)}{\sqrt{\operatorname{var}(d k)}}
$$

The preceding step is referenced to the inverse sequence, so we get another curve $U B$, and then the intersection of the two curves is defined as the abrupt change time. All tests are at the $\alpha=0.05$ significance level.

\section{DVM method}

$20 D V M$ is a new method we proposed to analyse the rationality and reliability of the result. In this study, 10 indexes of rainfall data, including EX (mathematical expectation), CV (deviation coefficient), CS (skewness coefficient), R10P (10\% quantile rainfall), R70P (70\% quantile rainfall), R90P (90\% quantile rainfall), CDD (the longest continuous rain free days), CWD (the longest continuous rain days), DR20 (days of heavy rain (more than $20 \mathrm{~mm} / \mathrm{d}$ per year on average)), and R20 (amount of heavy rain (more than $20 \mathrm{~mm} / \mathrm{d}$ per year on average)) were used to evaluate the change degree of rainfall before and after the

25 determined abrupt change time. The greater the variability degree of rainfall before and after the abrupt change time, the more rational and reliable the time was determined to be. The variability degree of rainfall can be calculated as follows:

$$
D_{0}=\left(\frac{1}{10} \sum_{j=1}^{10} D_{j}^{2}\right)^{1 / 2} \times 100 \%
$$


Nat. Hazards Earth Syst. Sci. Discuss., https://doi.org/10.5194/nhess-2018-194

Manuscript under review for journal Nat. Hazards Earth Syst. Sci.

Discussion started: 5 September 2018

(C) Author(s) 2018. CC BY 4.0 License.

\section{(c) (i)}

$$
D_{j}=\left|\frac{N_{\text {after }}-N_{\text {before }}}{N_{\text {before }}}\right| \times 100 \%
$$

where $D_{0}$ is the variability degree of precipitation, $D_{j}$ is the variability degree of the $j$ index, $N_{a f t e r}$ is the index value after the abrupt change time, and $N_{\text {before }}$ is the index value before the abrupt change time. When $\left|D_{0}\right|<25 \%$, the variability degree of rainfall is extremely low before and after the abrupt change time, which means the determined abrupt

5 change time is not reliable. A range of $25 \%<\left|D_{0}\right|<50 \%$ indicates that the variability degree of rainfall is moderate before and after the abrupt change time, such that the reliability of the determined abrupt change time is also moderate. $50 \%<\left|D_{0}\right|<75 \%$ shows that the variability degree of rainfall is relatively high before and after the abrupt change time and that the reliability of the determined abrupt change time is high. $\left|D_{0}\right|>75 \%$ indicates that the rainfall changes significantly before and after the abrupt change time and the reliability of the determined abrupt time is very high.

\section{3. 2.3 Period analysis methods}

Wavelet analysis is a new technique in the field of time frequency analysis that has developed rapidly in recent years. In this paper, the Morlet wavelet is used and the basic steps of Morlet wavelet analysis are given below.

\section{Wavelet function}

The wavelet function we applied is $\psi(t) \in L^{2}(R)$, which satisfies the following (Labat et al., 2010):

15

$$
\int_{-\infty}^{+\infty} \psi(T) d t=0
$$

where $\psi(t)$ is called the wavelet basis function. It aims to generate a sub-wavelet (Yu et al., 2012):

$$
\psi_{a, b}(t)=|a|^{-0.5} \psi\left(\frac{t-b}{a}\right)
$$

where $a, b \in R, a \neq 0 \circ \psi_{a, b}(t)$ is the sub-wavelet, $a$ represents the period length of wavelet, and $b$ is the time translation factor.

20 Wavelet transform

$\psi_{a, b}(t)$ is the sub-wavelet given by formula (14), which is discrete due to the studied rainfall series and set a $f(k \Delta t)(k=1,2, \ldots, N)$, where $\Delta t$ is the time interval. Then, the discrete wavelet transform can be expressed as:

$$
W_{f}(a, b)=\int_{-\infty}^{+\infty}|a|^{-0.5} \Delta t \sum_{k=1}^{n} f(k \Delta t) \bar{\psi}\left(\frac{k \Delta t-b}{a}\right)
$$


Nat. Hazards Earth Syst. Sci. Discuss., https://doi.org/10.5194/nhess-2018-194

Manuscript under review for journal Nat. Hazards Earth Syst. Sci.

Discussion started: 5 September 2018

(c) Author(s) 2018. CC BY 4.0 License.

(c) (i)

where $W_{f}(a, b)$ is the wavelet transform coefficient.
Natural Hazards

and Earth System

Sciences

Discussions

\section{3 Methods for Correlation analysis}

This study used Pearson correlation analysis and Grey correlation analysis method to study the correlation between rainfall and typhoons. Pearson correlation analysis is a relatively common correlation analysis method. Its principle is simple and the calculation is convenient. It can show the positive and negative relations between different elements and is not affected by changes in the variables' position and scale, but it cannot completely represent the tightness of the nonlinear relationship between the elements. If $R \in[0.6,1.0]$, the variables are strongly correlated, while $R \in[0.4,0.6)$ indicates a moderate correlation, $R \in[0.2,0.4)$ shows a weak correlation, and $R \in[0.0,0.2)$ indicates that there is no correlation (Xu, 2002).

\section{Grey correlation analysis method}

Grey correlation analysis method can describe complex nonlinear relationship between different elements. According to the geometric shape of factor data column, the close degree of the development situation is used to measure the close degree of the relationship between the factors, and there is no strict limitation on the length and distribution of the data sequence. Considering the interference of different dimensions on the conclusion, the data are processed to be dimensionless before

15 Grey correlation analysis. Commonly used dimensionless methods include initialization, averaging and standardization. Initialization is used in this study, and the formula is as follows (Liu, 2002):

$$
X_{i}^{\prime}(k)=\frac{X_{i}(k)}{X_{i}(1)}, k=1,2, \cdots n ; i=0,1,2 \cdots m
$$

The correlation coefficient of dimensionless reference sequence $X_{0}^{\prime}(k)$ and comparison sequence $X_{i}^{\prime}(k)$ at time $k$ can be obtained as follows:

$\xi_{i}(k)=\frac{\min _{i} \min _{k}\left|X_{0}^{\prime}(k)-X_{i}^{\prime}(k)\right|+\rho \max _{i} \max _{k}\left|X_{0}^{\prime}(k)-X_{i}^{\prime}(k)\right|}{X_{0}^{\prime}(k)-X_{i}^{\prime}(k)+\rho \max _{i} \max _{k}\left|X_{0}^{\prime}(k)-X_{i}^{\prime}(k)\right|}$

where $\rho$ is the resolution coefficient, and as suggested by (Zhu et al.,2015), $\rho$ is 0.5 in this study.

The average value of the correlation coefficient at each time is calculated as the correlation degree between the comparison sequence and the reference sequence. The calculation formula of correlation degree is as follows:

$$
r_{i}=\frac{1}{n} \sum_{k=1}^{n} \xi_{i}(k)
$$


Nat. Hazards Earth Syst. Sci. Discuss., https://doi.org/10.5194/nhess-2018-194

Manuscript under review for journal Nat. Hazards Earth Syst. Sci.

Discussion started: 5 September 2018

(c) Author(s) 2018. CC BY 4.0 License.

(c) (i)

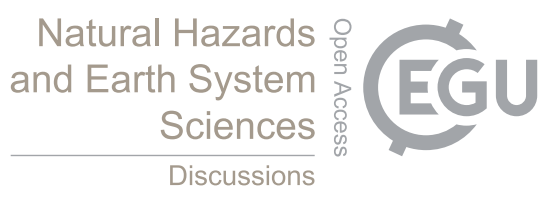

When the value of $r_{i}$ is above 0.8 , the relevance of the series is very strong; when $r_{i}$ is between 0.5 and 0.8 , it is considered to have a moderate correlation, and there is no correlation when $r_{i}$ is below 0.5 .

\section{Results}

\section{1 Inner-annual distribution}

5 The results of rainfall-averaged relative variability are shown in Figure 2 (a). As shown, the relative variability is relatively large, and the values are above $30 \%$. The maximum occurs in December, up to $77.54 \%$, while the relative variability of rainfall in June is relatively small, with a value of $34.29 \%$, indicating that the rainfall in December is more unstable than that in other months in Chengbi River Basin. In addition, PCD and PCP are used to further analyse the inner-annual distribution characteristics, as shown in Figure 2 (b) (c). The amplitude of variation in the PCD is relatively large, with a maximum of

100.71 (1974), while the minimum is only 0.32 (1983). Overall, the PCD shows a slight rising trend, meaning that the rainfall in Chengbi River Basin tends to be centralized, and the distribution throughout the year is more and more uneven. From Figure 2 (c), it is known that the PCP is relatively stable and the average is 190 degrees, which shows that the rainfall in Chengbi River Basin is mainly concentrated in July, which is basically the same time as the beginning of the main flood season (June-July) in Chengbi River Basin. In addition, the PCP shows a downward trend. With this trend, the occurrence

15 time of the main flood season in Chengbi River Basin may be advancing. 
Nat. Hazards Earth Syst. Sci. Discuss., https://doi.org/10.5194/nhess-2018-194

Manuscript under review for journal Nat. Hazards Earth Syst. Sci.

Discussion started: 5 September 2018

(C) Author(s) 2018. CC BY 4.0 License.

\section{(c) (i)}

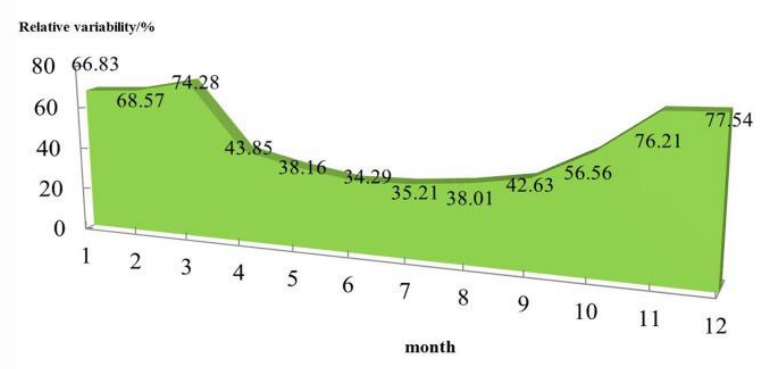

(a) relative variability

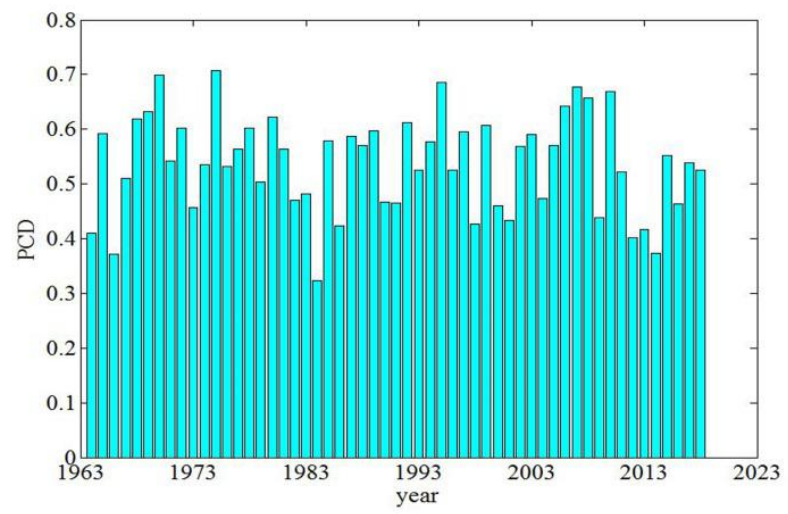

(b) PCD

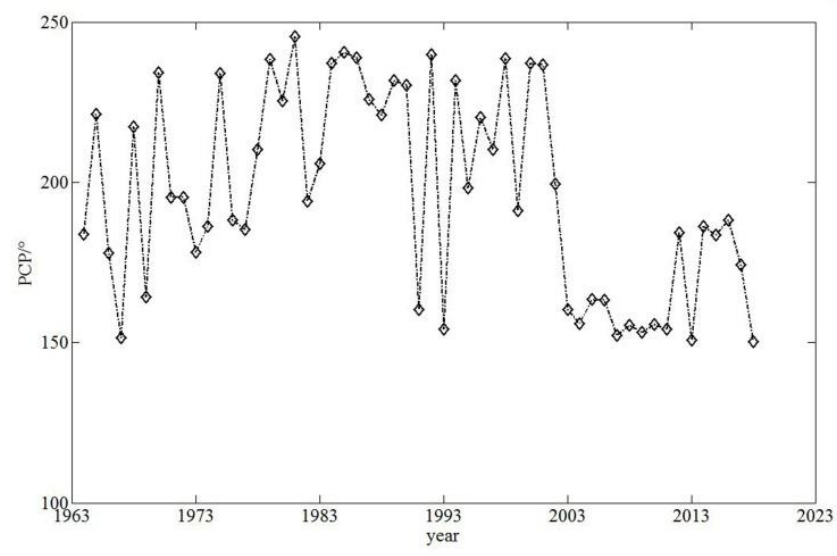

(c) PCP

Fig. 2 The results of Inner-annual distribution. (a) shows the relative variability of the monthly rainfall, (b) shows the PCD of the monthly rainfall, and (c) shows the PCP of the monthly rainfall.

\section{2 Inter-annual variation}

\section{4. 2.1 Trend analys is result}

Linear trend method and Sen+Mann-Kendall methods are used to analyse the trend of monthly and seasonal rainfall. The results are shown in Figure 3 and Table 1. According to Figure 3, in general, the monthly average rainfall is relatively stable, showing a very weak downward trend with a rate of decline of only $-0.243(\mathrm{~mm}$. 10a). The seasonal rainfall is relatively less stable, with rainfall in spring and summer showing a downward trend while rainfall in autumn and winter showing an upward trend. Next, we use the spring and autumn rainfall as an example. As can be seen from Figure 3 (b), the spring rainfall shows a downward trend in general, with a decrease rate of $-9.515(\mathrm{~mm} .10 \mathrm{a})$ and an average value of $245.25 \mathrm{~mm}$. The maximum value lies in 1967 (566.4 mm) and the minimum value $(120.9 \mathrm{~mm})$ lies in 1991 . In autumn, the rainfall is 
Nat. Hazards Earth Syst. Sci. Discuss., https://doi.org/10.5194/nhess-2018-194

Manuscript under review for journal Nat. Hazards Earth Syst. Sci.

Discussion started: 5 September 2018

(c) Author(s) 2018. CC BY 4.0 License.

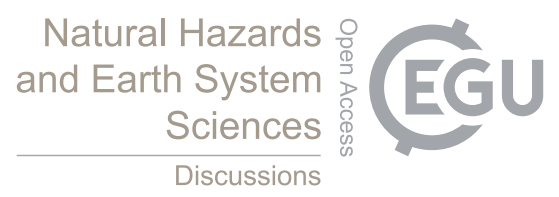

generally rising, the rise rate is $5.236(\mathrm{~mm} .10 \mathrm{a})$ and the average value is $209.74 \mathrm{~mm}$. The maximum value $(482.4 \mathrm{~mm})$ lies in 2008, and the minimum value $(69.1 \mathrm{~mm})$ lies in 1969, as shown in Figure 3 (d).

The results of Sen+Mann-Kendall trend analysis used to further analyse the significance of the rainfall trends are presented in Table 3. As shown, at the 5\% significance level, no significant trend is detected for all time scales, and $\mathrm{Z}$ statistics ranges

5 from -1.162 to 1.525 . On the seasonal scale, downward trends are detected in spring and summer (with $\beta$ of -0.781 and 0.681), while upward trends are detected in autumn and winter (with $\beta$ of 0.329 and 0.367). Moreover, on the monthly scale time, we can see that both the $\beta$ and the $Z$ statistic are close to zero, which indicates that the rainfall shows a relatively stable process.

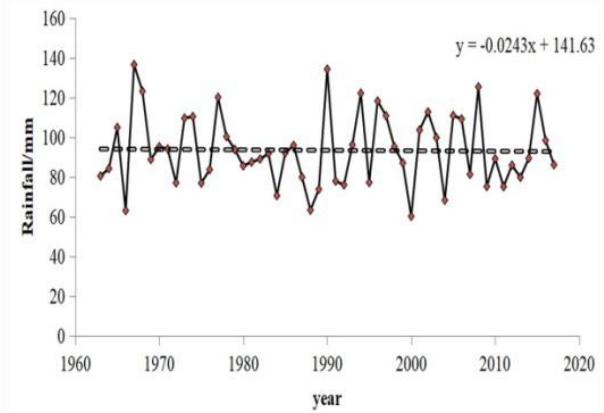

(a) monthly

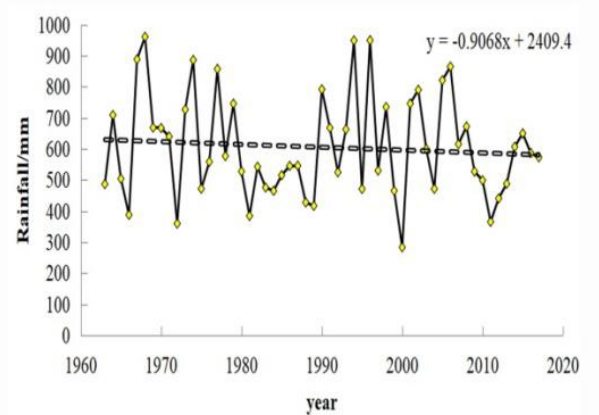

(c) summer

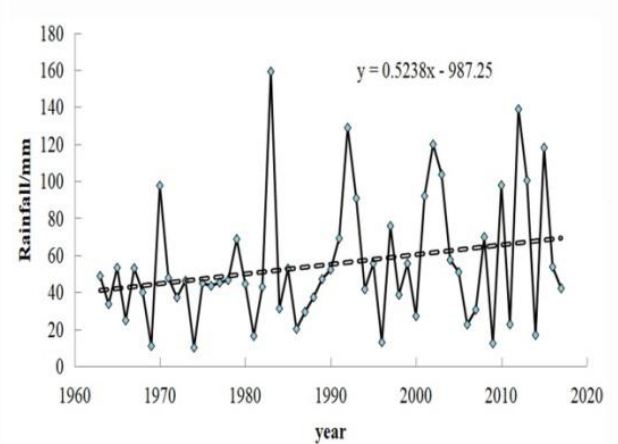

(e) winter

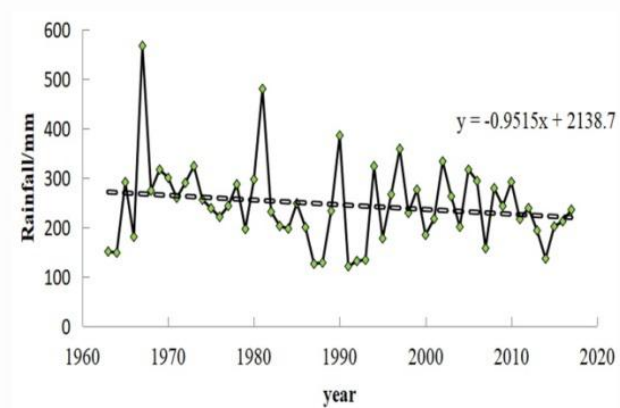

(b) spring

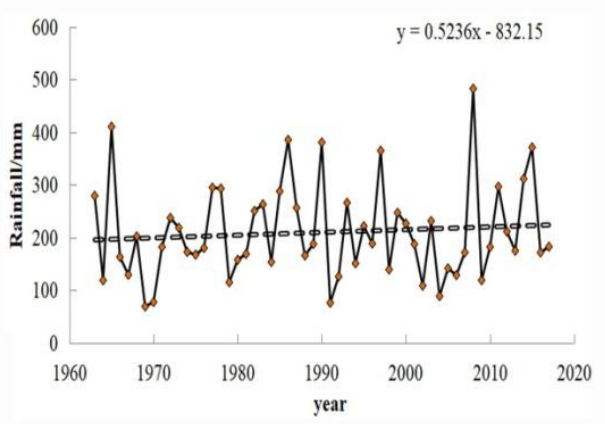

(d) autumn

10 Fig. 3 The linear trend analysis results of (a) monthly rainfall and seasonal rainfall (b, c, d, and e) during $1963-2017$. 
Nat. Hazards Earth Syst. Sci. Discuss., https://doi.org/10.5194/nhess-2018-194

Manuscript under review for journal Nat. Hazards Earth Syst. Sci.

Discussion started: 5 September 2018

(c) Author(s) 2018. CC BY 4.0 License.

(c) (i)
Natural Hazards

and Earth System

Sciences

Discussions

Table 1. Trend analysis results using the Sen+Mann-Kendall method.

\begin{tabular}{ccccc}
\hline Time scale & Mean/mm & $\beta$ & Z statistic & Comprehensive results \\
\hline Monthly average & 93.34 & -0.025 & -0.094 & $\begin{array}{c}\text { Not significant } \\
\text { downward trend } \\
\text { Not significant } \\
\text { downward trend } \\
\text { Spring }\end{array}$ \\
Summer & 604.93 & -0.781 & -1.162 & $\begin{array}{c}\text { Not significant } \\
\text { downward trend } \\
\text { Not significant upward } \\
\text { trend } \\
\text { Autumn }\end{array}$ \\
Winter & -0.681 & -0.493 & 0.581 & $\begin{array}{c}\text { Not significant upward } \\
\text { trend }\end{array}$ \\
\hline
\end{tabular}

\section{2. 2 Abrupt change time analysis result}

As seen from Figure 4, the Mann-Kendall test curve $U F$ and $U B$ of the monthly rainfall series have obvious intersection points approximately 1975, 1995, 2005 and 2014. Considering that 2014 is too close to the end of the series, the result is not

5 reliable enough if we consider 2014 to be an abrupt change time, so we exclude it. As a result, 1975, 1995 and 2005 are the possible abrupt change times in the monthly rainfall data. Similarly, the possible abrupt change times of the spring rainfall data are approximately 1982, 1996 and 2009, while the possible abrupt change times of the summer rainfall data are approximately 1973, 1979, 1993 and 2008 and the possible abrupt change times of the autumn rainfall series are approximately 1975, 1990, 1997 and 2009. Finally, the possible abrupt change time of the winter rainfall series is

10 approximately 1990. A hydrological variation diagnosis system is used for a comprehensive detection of the abrupt change time, and the years corresponding to the maximum frequency are finally identified as the abrupt change time. Using the monthly rainfall sequence as an example, 1979 is the most frequent in all results, and the frequency value is 0.571. Sequential clustering, sliding T, sliding F, and Lee-Heghinan all show that abrupt change may appear in 1979, so 1979 is finally identified as the abrupt change time for monthly series. Likewise, 1982 is finally identified as the abrupt change time

15 for spring series, 1979and 2008 are the abrupt change times for summer series, and 1996 and 1990 are the abrupt change times for autumn and winter series, respectively. Table 3 shows the reliability test results of the abrupt change time for monthly and seasonal rainfall data. As shown, for the single index, we can see that the $\mathrm{D}_{\mathrm{j}}$ value of Cs is the largest, indicating that the change in Cs is the greatest before and after the abrupt change time and that Cs is most susceptible to the variation in rainfall. The $\mathrm{D}_{0}$ values of monthly and summer (when the determined abrupt change time is 2008) rainfall data

20 are less than $25 \%$, which show that there is no reliability of the determined abrupt change time for the above two data series. As a result, this suggests that there is no abrupt change time for monthly rainfall series and that 2008 cannot be the abrupt change time for summer rainfall series. For spring and autumn rainfall series, the determined abrupt change time (1982 and 
Nat. Hazards Earth Syst. Sci. Discuss., https://doi.org/10.5194/nhess-2018-194

Manuscript under review for journal Nat. Hazards Earth Syst. Sci.

Discussion started: 5 September 2018

(c) Author(s) 2018. CC BY 4.0 License.

(c) (1)

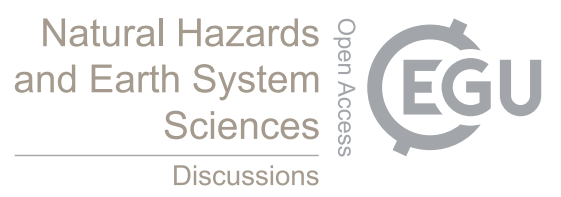

1996) carry moderate reliability, and they can be seen as the abrupt change time of spring and autumn rainfall series. For summer (when the determined abrupt change time is 1979) and winter rainfall data, the values of $\mathrm{D}_{0}$ are larger than $50 \%$, which means that 1979 and 1990 can be regarded as the abrupt change times of summer and winter rainfall series, and the determined abrupt change times carry strong reliability.

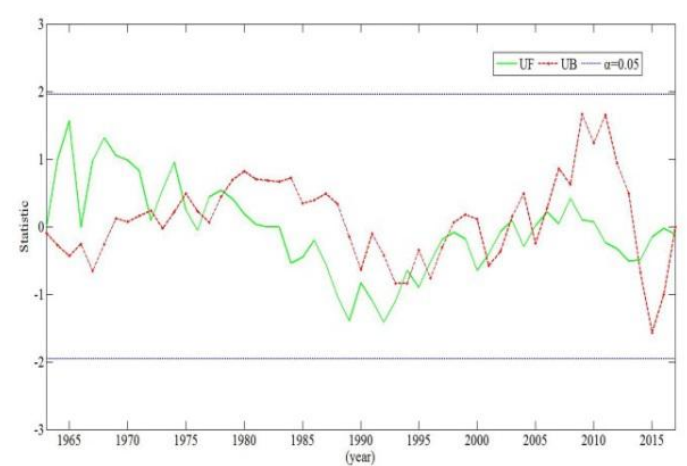

(a) monthly

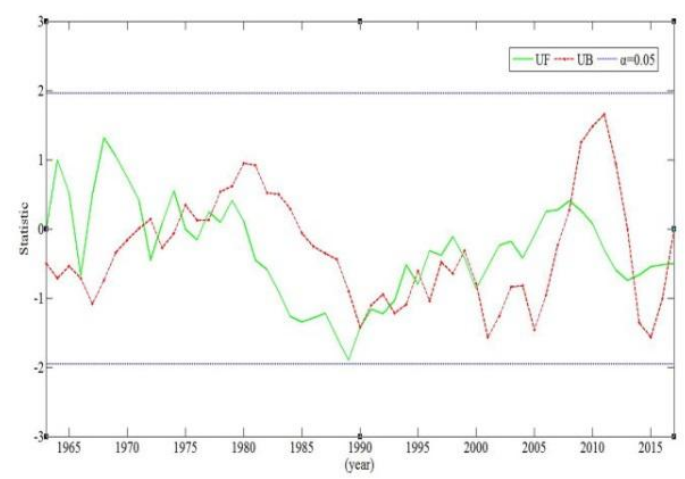

(c) summer

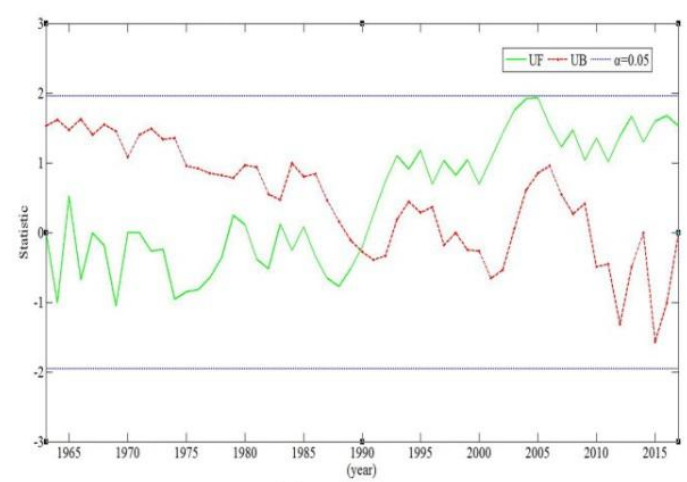

(e) winter

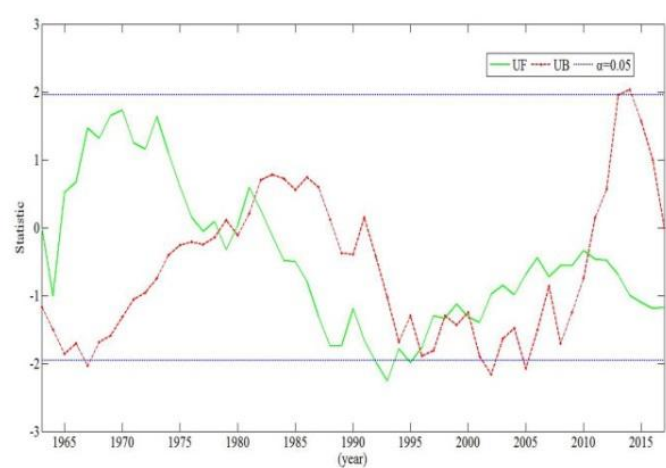

(b) spring

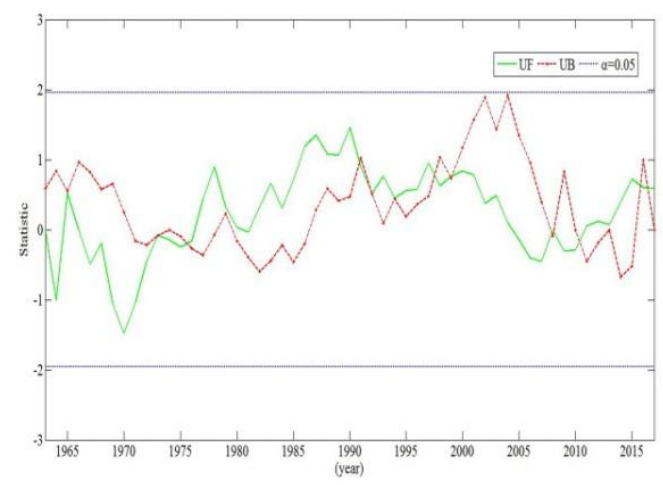

(d) autumn

Fig. 4 Mann-Kendall test results of (a) monthly rainfall and seasonal rainfall (b, $c$, d, and e) during 1963-2017. The intersections of the curve UF (green line) and curve UB (red line) are defined as the abrupt change time. All tests are at the significance level $\alpha=0.05$. 
Nat. Hazards Earth Syst. Sci. Discuss., https://doi.org/10.5194/nhess-2018-194

Manuscript under review for journal Nat. Hazards Earth Syst. Sci.

Discussion started: 5 September 2018

(c) Author(s) 2018. CC BY 4.0 License.

(c) (9)
Natural Hazards and Earth System

Sciences

Discussions

Table 2 Comprehensive detection results of abrupt change time

\begin{tabular}{|c|c|c|c|c|}
\hline Time scale & $\begin{array}{l}\text { Possible abrupt } \\
\text { change time }\end{array}$ & Frequency & Methods & $\begin{array}{c}\text { Abrupt } \\
\text { change } \\
\text { time }\end{array}$ \\
\hline \multirow{5}{*}{ Monthly average } & 1975 & 0.285 & Sliding Rank Sum, Mann-Kendall & \multirow{5}{*}{1979} \\
\hline & 1979 & 0.571 & $\begin{array}{c}\text { Sequential Clustering, Sliding T, Sliding F, Lee- } \\
\text { Heghinan }\end{array}$ & \\
\hline & 1980 & 0.143 & Cumulative Anomaly & \\
\hline & 1995 & 0.143 & Mann-Kendall & \\
\hline & 2005 & 0.143 & Mann-Kendall & \\
\hline \multirow{4}{*}{ Spring } & 1964 & 0.143 & Sliding Rank Sum & \multirow{4}{*}{1982} \\
\hline & 1982 & 0.714 & $\begin{array}{c}\text { Cumulative Anomaly, Sequential Clustering, Lee- } \\
\text { Heghinan, Sliding T, Mann-Kendall }\end{array}$ & \\
\hline & 1996 & 0.143 & Mann-Kendall & \\
\hline & 2009 & 0.285 & Sliding F, Mann-Kendall & \\
\hline \multirow{4}{*}{ Summer } & 1973 & 0.143 & Mann-Kendall & \multirow{4}{*}{1979,2008} \\
\hline & 1979 & 0.571 & $\begin{array}{l}\text { Cumulative Anomaly, Lee-Heghinan, Sliding T, Mann- } \\
\text { Kendall }\end{array}$ & \\
\hline & 1993 & 0.143 & Mann-Kendall & \\
\hline & 2008 & 0.571 & $\begin{array}{l}\text { Sequential Clustering, Sliding F, Sliding Rank Sum, } \\
\text { Mann-Kendall }\end{array}$ & \\
\hline \multirow{4}{*}{ Autumn } & 1975 & 0.429 & Mann-Kendall, Sliding F, Sliding Rank Sum & \multirow{4}{*}{1996} \\
\hline & 1990 & 0.143 & Mann-Kendall & \\
\hline & 1996 & 0.714 & $\begin{array}{c}\text { Mann-Kendall, Cumulative Anomaly, Sequential } \\
\text { Clustering, Lee-Heghinan, Sliding T }\end{array}$ & \\
\hline & 2009 & 0.143 & Mann-Kendall & \\
\hline \multirow{3}{*}{ Winter } & 1968 & 0.143 & Sliding F & \multirow{3}{*}{1990} \\
\hline & 1982 & 0.142 & Lee-Heghinan & \\
\hline & 1990 & 0.714 & $\begin{array}{l}\text { Mann-Kendall, Cumulative Anomaly, Sequential } \\
\text { Clustering, Sliding T, Sliding Rank Sum }\end{array}$ & \\
\hline
\end{tabular}


Nat. Hazards Earth Syst. Sci. Discuss., https://doi.org/10.5194/nhess-2018-194

Manuscript under review for journal Nat. Hazards Earth Syst. Sci.

Discussion started: 5 September 2018

(C) Author(s) 2018. CC BY 4.0 License.

(c) (i)
Natural Hazards and Earth System

Sciences

Discussions

Table 3 Reliability test results of the determined abrupt change time

\begin{tabular}{|c|c|c|c|c|c|c|c|c|c|c|c|c|}
\hline $\begin{array}{l}\text { Time } \\
\text { scale }\end{array}$ & $\begin{array}{l}\text { Abrupt } \\
\text { change } \\
\text { time }\end{array}$ & $\mathrm{D}_{\mathrm{j}}(\mathrm{EX})$ & $\mathrm{D}_{\mathrm{j}}(\mathrm{CV})$ & $\mathrm{D}_{\mathrm{j}}(\mathrm{CS})$ & $\begin{array}{c}D_{j} \\
(R 10)\end{array}$ & $\begin{array}{c}\mathrm{D}_{\mathrm{j}} \\
(\mathrm{R} 70)\end{array}$ & $\begin{array}{c}\mathrm{D}_{\mathrm{j}} \\
(\mathrm{R} 90)\end{array}$ & $\begin{array}{c}\mathrm{D}_{\mathrm{j}} \\
(\mathrm{CDD})\end{array}$ & $\begin{array}{c}\mathrm{D}_{\mathrm{j}} \\
(\mathrm{CWD})\end{array}$ & $\begin{array}{c}D_{j} \\
(D R 20)\end{array}$ & $\mathrm{D}_{\mathrm{j}}(\mathrm{R} 20)$ & $\mathrm{D}_{0}$ \\
\hline Monthly & 1979 & $4.88 \%$ & $4.76 \%$ & $22.03 \%$ & $5.78 \%$ & $4.48 \%$ & $2.79 \%$ & $11.40 \%$ & $8.25 \%$ & $3.40 \%$ & $11.29 \%$ & $9.64 \%$ \\
\hline Spring & 1982 & $18.80 \%$ & $14.29 \%$ & $64.88 \%$ & $22.80 \%$ & $13.61 \%$ & $18.16 \%$ & $17.93 \%$ & $7.95 \%$ & $21.62 \%$ & $28.55 \%$ & $27.33 \%$ \\
\hline \multirow{3}{*}{ Summer } & 1979 & $9.07 \%$ & $6.67 \%$ & $240.74 \%$ & $10.19 \%$ & $9.63 \%$ & $1.13 \%$ & $5.89 \%$ & $12.71 \%$ & $5.59 \%$ & $14.11 \%$ & $76.62 \%$ \\
\hline & & & & & & & & & & & & \\
\hline & 2008 & $12.71 \%$ & $34.48 \%$ & $45.16 \%$ & $21.30 \%$ & $5.98 \%$ & $2.20 \%$ & $26.25 \%$ & $23.79 \%$ & $12.89 \%$ & $25.96 \%$ & $24.44 \%$ \\
\hline Autumn & 1996 & $4.14 \%$ & $11.63 \%$ & $102.47 \%$ & $8.26 \%$ & $2.73 \%$ & $9.97 \%$ & $29.67 \%$ & $25.28 \%$ & $38.89 \%$ & $15.23 \%$ & $37.54 \%$ \\
\hline Winter & 1990 & $40.68 \%$ & $7.14 \%$ & $66.20 \%$ & $46.99 \%$ & $40.67 \%$ & $20.61 \%$ & $11.68 \%$ & $19.24 \%$ & $56.67 \%$ & $118.17 \%$ & $50.97 \%$ \\
\hline
\end{tabular}

\section{2. 3 Period analysis results}

5 In this paper, we mainly use the real part of wavelet coefficient values and the wavelet variance value to analyse the period characteristic. The real part of the wavelet coefficient can reflect the periodic variation over different time scales and can reflect the distribution in the time domain. In figure 5, time (year) is expressed in the horizontal coordinate, whereas the time scale (the period) is represented in the vertical coordinate. As shown, there are multiple time scale characteristics of the monthly and seasonal rainfall series in Chengbi River Basin. In general, the monthly rainfall series has a periodic variation at

10 5-30a scale, and there is a periodic variation at 4-28a scale in seasonal rainfall. Specifically, there are 6-12a and 15-28a periods in spring, 4-6 $a$ and 14-22 $a$ periods in summer, 4-9 $a$ and 15-18a periods in autumn, and 13-16a periods in winter. 
Nat. Hazards Earth Syst. Sci. Discuss., https://doi.org/10.5194/nhess-2018-194

Manuscript under review for journal Nat. Hazards Earth Syst. Sci.

Discussion started: 5 September 2018

(c) Author(s) 2018. CC BY 4.0 License.

(c) (i)

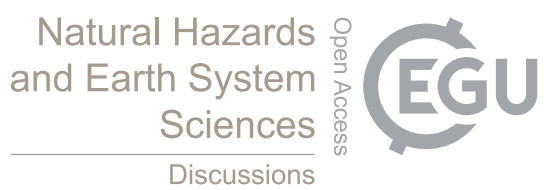

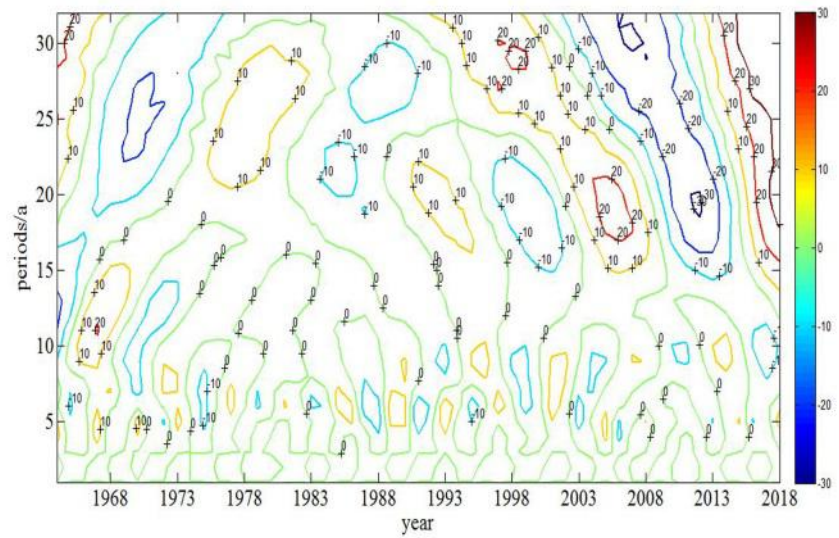

(a) monthly

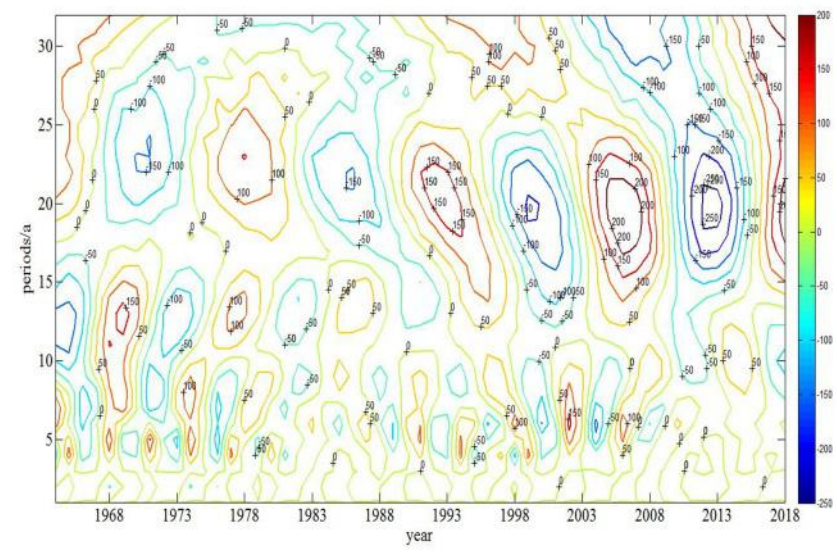

(c) summer

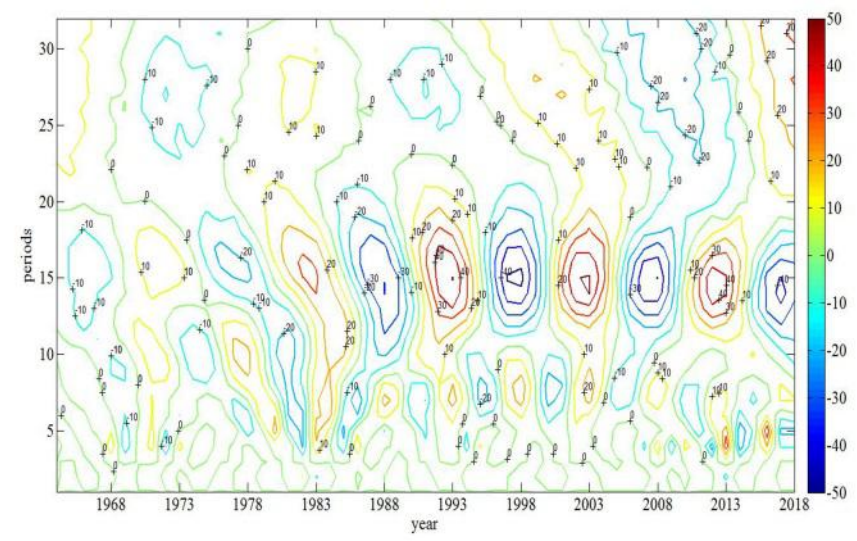

(e) winter

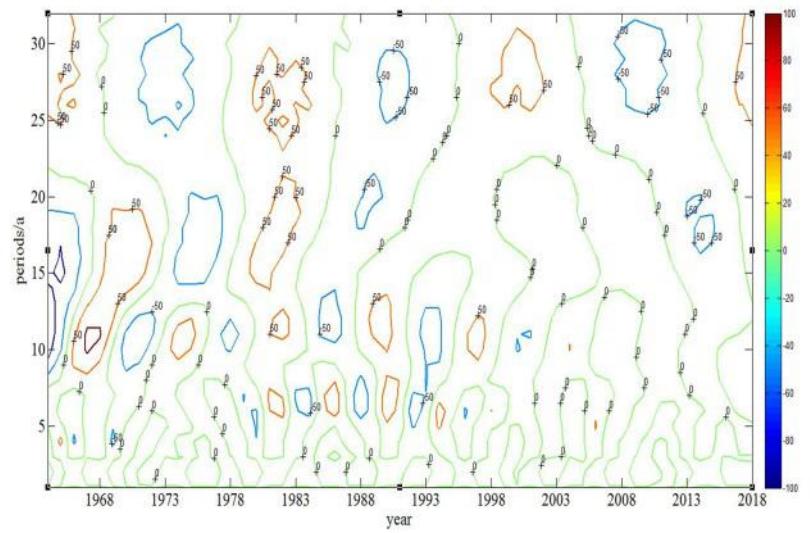

(b) spring

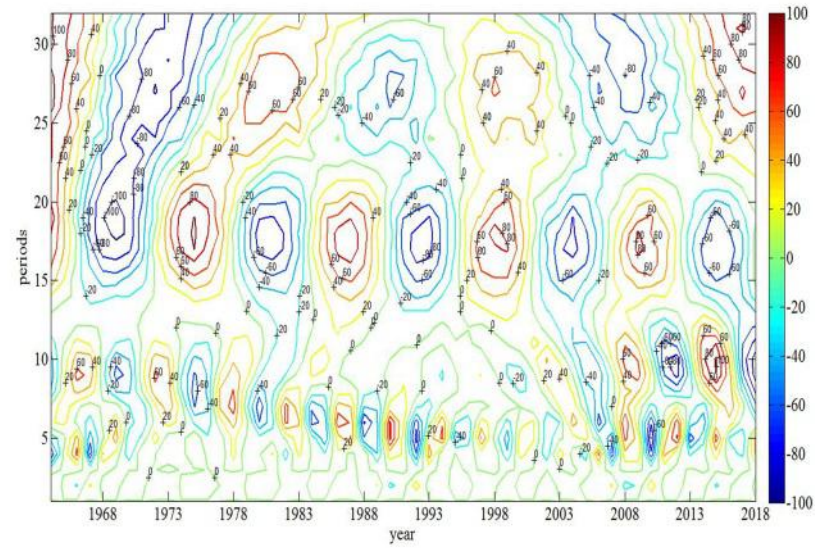

(d) autumn

Fig. 5 Real parts of Morlet wavelet transform coefficients of (a) monthly rainfall and seasonal rainfall (b, c, d, e) during $1963-2017$. 
Nat. Hazards Earth Syst. Sci. Discuss., https://doi.org/10.5194/nhess-2018-194

Manuscript under review for journal Nat. Hazards Earth Syst. Sci.

Discussion started: 5 September 2018

(c) Author(s) 2018. CC BY 4.0 License.

(c) (i)

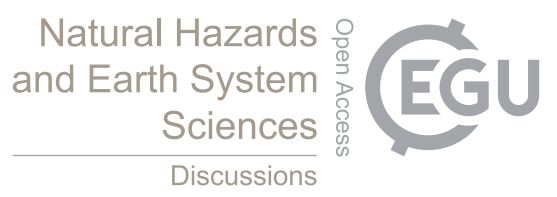

In addition, the main periods of monthly and seasonal rainfall are further analysed using wavelet variance. Wavelet variance can show the distribution of energy of each time scale, and it can be applied to determine the main period. As shown in Figure 6, the ordinate is the variance of the wavelet and the abscissa is the period. Taking the monthly rainfall series as an example, it is shown that there are 2 obvious peaks in the wavelet variance of the monthly mean rainfall series from Figure 6 (a), in which the peak value of $29 a$ is the largest, indicating that the $29 a$ periodic oscillation is the strongest, which is the first main period of the monthly average rainfall series and that the $21 a$ time scale is the hypo-period. For spring rainfall, the first main period is $11 a$, and the hypo-period is $28 a$. The first main period of summer rainfall is $21 a$, and the hypo-period is $6 a$. The first main period of autumn rainfall is $17 a$, and the hypo-period is $28 a$. The first main period of winter rainfall is $15 a$, and the hypo-period is $7 \mathrm{a}$. It can be seen that the main periods of rainfall in summer and winter are shorter than those in spring and autumn.

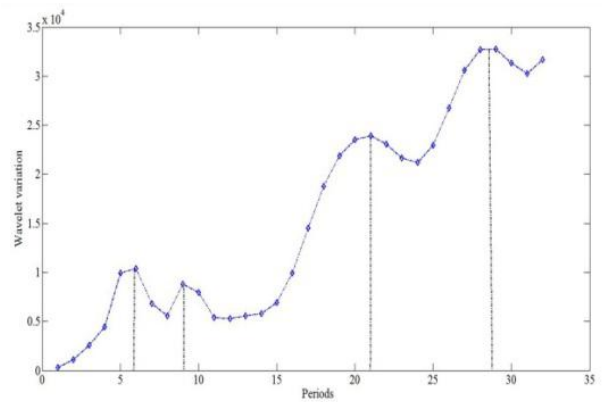

(a) monthly

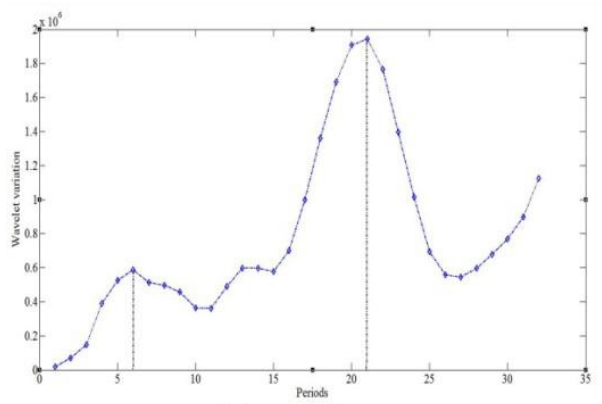

(c) summer

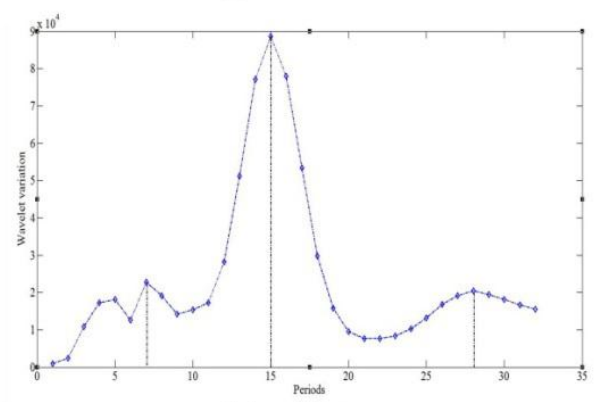

(e) winter

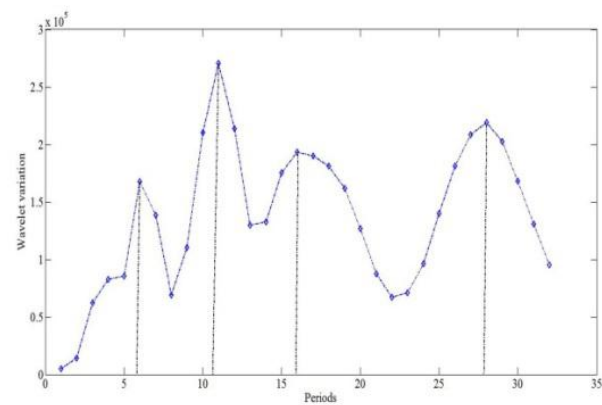

(b) spring

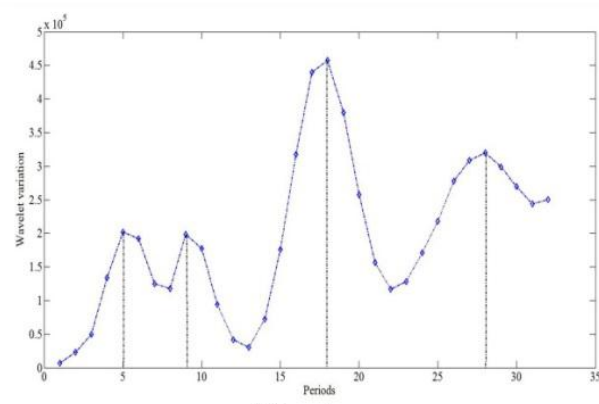

(d) autumn

Fig. 6 Variance diagram Morlet wavelet of (a) monthly rainfall and seasonal rainfall (b, c, d, and e) during 1963-2017. Peaks in the wavelet variance diagram indicate the main periods. 
Nat. Hazards Earth Syst. Sci. Discuss., https://doi.org/10.5194/nhess-2018-194

Manuscript under review for journal Nat. Hazards Earth Syst. Sci.

Discussion started: 5 September 2018

(c) Author(s) 2018. CC BY 4.0 License.

(c) (i)

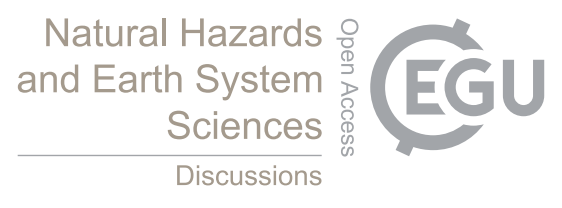

\section{2. 4 The results of correlation analysis}

To further grasp the correlation between rainfall and typhoons in Chengbi River Basin, the relationship between the summerautumn rainfall series and the related parameters of typhoons is analysed (the typhoon influence periods in the Chengbi River Basin are summer and autumn). The typhoon parameters used include the number of typhoons per year, the typhoon maintaining time, the maximum typhoon wind speed and the typhoon-caused rain. As shown in Figure 7, Chengbi River Basin is affected by 2 typhoons on average every year. Some years (such as 1995) are affected by typhoons up to 5 times, and some years are not influenced by typhoons. The average annual typhoon influence time is up to 80 hours (over approximately 3 days) and the average annual typhoon-caused rainfall is $94.72 \mathrm{~mm}$. In 1967 the rainfall was most affected by typhoons, and the typhoon-caused rainfall reached $438 \mathrm{~mm}$. The average maximum wind speed of the typhoon is $22.4 \mathrm{~m} / \mathrm{s}$.

10 Due to Chengbi River Basin was not affected by typhoons in 1983, 1988, 1997, 2004, 2005, and 2011, the relationship between rainfall and typhoons in this above 6 years is not analysed. Table 4 shows the correlation between summer rainfall and typhoon parameters. As shown, the typhoon-caused rain is the main factor affecting the summer rainfall (the Pearson and Grey correlation coefficients are 0.675 and 0.793 ), followed by maximum wind speed (the Pearson and Grey correlation coefficients are -0.563 and 0.672 ) and typhoon maintaining time (the Pearson and Grey correlation coefficients are 0.528 and

15 0.633), and finally the number of typhoons has least influence on summer rainfall (the Pearson and Grey correlation coefficients are just 0.216 and 0.456 ). For autumn rainfall, as shown in Table 5, the typhoon-caused rain is also the main factor (the Pearson and Grey correlation coefficients are 0.772 and 0.835 ), followed by the maintaining time and maximum wind speed, and finally the number of typhoons has the least influence (the Pearson and Grey correlation coefficients are 0.336 and 0.557 ). Through the comprehensive analysis of tables 4 and 5, we can draw the following conclusion: the 20 correlation between typhoons and autumn rainfall is generally more significant than that between typhoons and summer rainfall. 
Nat. Hazards Earth Syst. Sci. Discuss., https://doi.org/10.5194/nhess-2018-194

Manuscript under review for journal Nat. Hazards Earth Syst. Sci.

Discussion started: 5 September 2018

(c) Author(s) 2018. CC BY 4.0 License.

\section{(c) (1)}

Natural Hazards and Earth System Sciences

Discussions

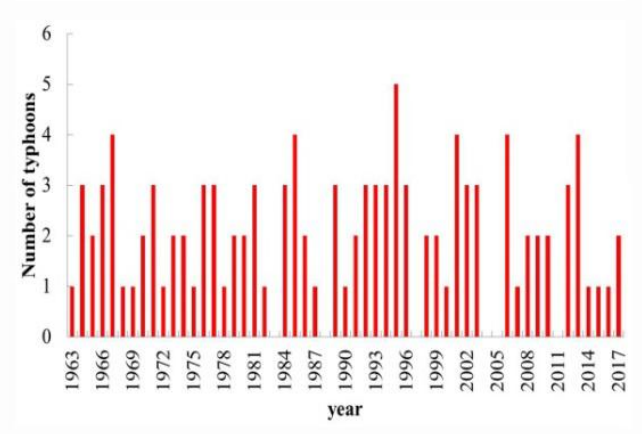

(a)

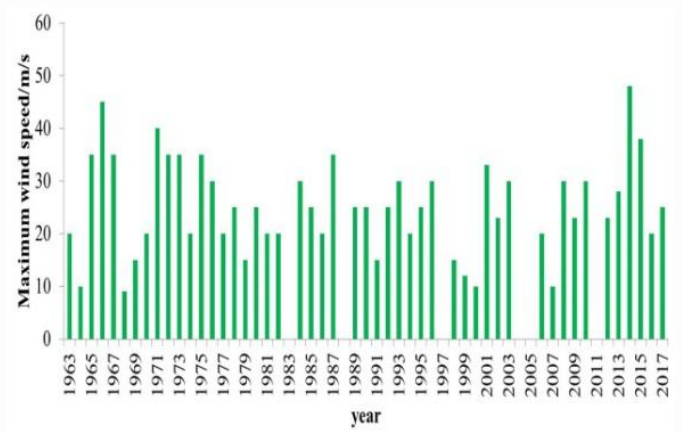

(c)

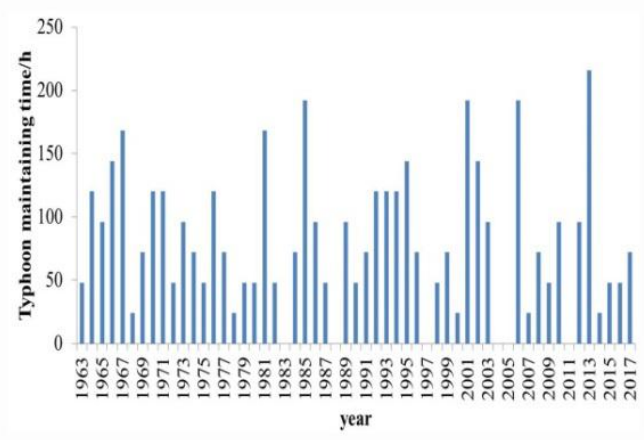

(b)

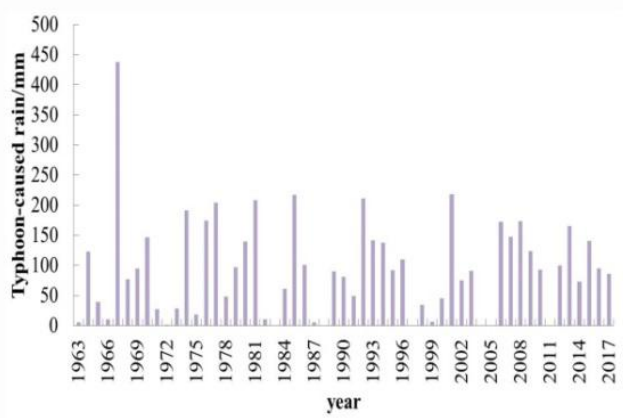

(d)

Fig. 7 The selected typhoons parameters including (a) the number of typhoons, (b) the typhoons maintaining time, (c) the maximum wind speed and (d) the typhoon-caused rain.

5 Table 4 Correlation between summer rainfall and typhoon parameters

\begin{tabular}{ccccccccc}
\hline & $\begin{array}{c}\text { Number of } \\
\text { typhoons }\end{array}$ & $\begin{array}{c}\text { Correlation } \\
\text { degree }\end{array}$ & $\begin{array}{c}\text { Typhoon } \\
\text { maintaining } \\
\text { time }\end{array}$ & $\begin{array}{c}\text { Correlation } \\
\text { degree }\end{array}$ & $\begin{array}{c}\text { Maximum } \\
\text { wind speed }\end{array}$ & $\begin{array}{c}\text { Correlation } \\
\text { degree }\end{array}$ & $\begin{array}{c}\text { Typhoon- } \\
\text { caused rain }\end{array}$ & $\begin{array}{c}\text { Correlation } \\
\text { degree }\end{array}$ \\
\hline Pearson & 0.216 & weak & 0.528 & moderate & -0.563 & moderate & 0.675 & strong \\
Grey & 0.456 & weak & 0.633 & moderate & 0.672 & moderate & 0.793 & moderate \\
\hline
\end{tabular}

Table 5 Correlation between autumn rainfall and typhoon parameters

\begin{tabular}{ccccccccc}
\hline & $\begin{array}{c}\text { Number of } \\
\text { typhoons }\end{array}$ & $\begin{array}{c}\text { Correlation } \\
\text { degree }\end{array}$ & $\begin{array}{c}\text { Typhoon } \\
\text { maintaining } \\
\text { time }\end{array}$ & $\begin{array}{c}\text { Correlation } \\
\text { degree }\end{array}$ & $\begin{array}{c}\text { Maximum } \\
\text { wind speed }\end{array}$ & $\begin{array}{c}\text { Correlation } \\
\text { degree }\end{array}$ & $\begin{array}{c}\text { Typhoon- } \\
\text { caused rain }\end{array}$ & $\begin{array}{c}\text { Correlation } \\
\text { degree }\end{array}$ \\
\hline $\begin{array}{c}\text { Pearson } \\
\text { Grey }\end{array}$ & 0.336 & weak & 0.673 & strong & -0.594 & moderate & 0.772 & strong \\
moderate & 0.557 & moderate & 0.699 & moderate & 0.835 & strong \\
\hline
\end{tabular}


Nat. Hazards Earth Syst. Sci. Discuss., https://doi.org/10.5194/nhess-2018-194

Manuscript under review for journal Nat. Hazards Earth Syst. Sci.

Discussion started: 5 September 2018

(c) Author(s) 2018. CC BY 4.0 License.

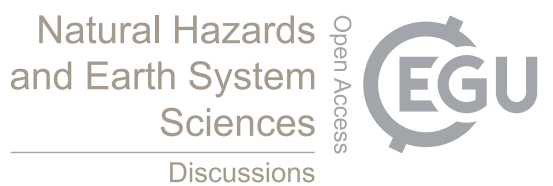

\section{Discussion and practical suggestions}

\section{1 Discussion}

(1) The seasonal rainfalls in Chengbi River Basin show different trends. For example, the rainfall in spring shows a downward trend, while autumn rainfall shows an upward trend. In addition to the influence of typhoons, this may also be

5 related to the aerosol content in the air. Some studies have shown that air aerosols in the Chengbi River Basin are increasing, and in Chengbi River Basin, the rainfall in spring is mainly frontal rain, and the increase in aerosol material will inhibit frontal rain. The increase in aerosol material in the air increases the density of the heating mass, which is not conducive to the rising movement of the warm air mass, thus reducing the possibility of rainfall. In autumn, the rainfall is mainly cyclonic rain and typhoon rain, and the cyclone systems have abundant water vapours. The increase in aerosols can provide sufficient

10 condensate for a large amount of water vapours and promote rainfall.

(2) Through the analysis of the abrupt change time, we know that the rainfall in the Chengbi River Basin mainly changed from the 1980s to 1990s. What accounts for this? Usually, the abrupt change time of a rainfall series can be seen as the time when climate change begins. Two factors may influence the climate change: one is the influence of global warming, and many studies show that the 1990s is a significant period when the climate is affected by global warming in southern China.

15 Another factor may be the afforestation; according to the statistics, the forest areas of the Chengbi River Basin increased from $41495.27 \mathrm{hm}^{2}(1970 \mathrm{~s})$ to $150269.9 \mathrm{hm}^{2}(1990 \mathrm{~s})$, and the vegetation coverage increased from $20.37 \%$ to $59.98 \%$. The coverage of the forest leaf area and the consumption of $\mathrm{CO}_{2}$ by plant photosynthesis may change the local climate pattern. In addition, this study shows that abrupt changes in seasonal precipitation occur in different years. This is similar to the results of previous studies (Zou et al.,2016;Mo et al.,2018).This also means that there are some differences in the mechanism and

20 cause of abrupt changes of rainfall in different seasons. As stated by(Chen,2009), the abrupt changes in summer and autumn rainfall are more likely to be caused by monsoon system anomalies, while the abrupt changes in spring and winter rainfall are associated with temperature anomalies. More specific mechanisms and causes still need to be further studied in the future.

\section{2 Practical suggestions}

(1) Traditionally, the main factor for judging drought and flood disasters is the amount of rainfall, and when we distinguish

25 between drought and flood years, we usually use an annual precipitation index or drought and flood index. However, PCD and PCP are closely related to the occurrence of drought and flood, the larger the PCD, the more concentrated rainfall is in flood season, and the greater the possibility of flooding. And change in PCP reflects the change in flood time. Therefore, it is suggested that not only the amount of rainfall should be considered when studying drought and flood characteristics but also the PCD and PCP characteristics of rainfall. In addition, through the study of rainfall characteristics in Chengbi River Basin,

30 it is found that the rainfall PCD shows an increasing trend. It is generally believed that the larger the PCD, the easier it is to cause flood disasters. Thus, we suggest that local water administration departments should strengthen preventive measures for flood and waterlogging disasters. In addition, the PCP presented a downward trend, which means that the main flood 
Nat. Hazards Earth Syst. Sci. Discuss., https://doi.org/10.5194/nhess-2018-194

Manuscript under review for journal Nat. Hazards Earth Syst. Sci.

Discussion started: 5 September 2018

(c) Author(s) 2018. CC BY 4.0 License.
Natural Hazards

and Earth System

Sciences

Discussions

(c) $\underset{\mathrm{BY}}{\mathrm{B}}$

season may come advance in the Chengbi River Basin. It is suggested that the initial time of the main flood season in the basin should be restudied in the context of climate change, thus providing a more scientific and reliable basis for local water management work.

(2) This study found that the monthly and seasonal rainfall characteristics of the Chengbi River Basin are more complex, the

5 monthly rainfall distribution is uneven, and the seasonal rainfall shows significant seasonal characteristics. We suggest that the reservoir management department of Chengbi River Basin should segment the flood season into flood sub-seasons (usually divided into pre-flood season, the main flood season and post-flood season) and that the reservoir should be operated at different FLWLs. This means that the reservoir should be operated at a lower FLWL during periods of concentrated rainfall (pre-flood season and main flood season) and a higher FLWL for the post-flood season to use the

10 rainwater more effectively and prevent the possible floods or droughts.

(3) This study shows that abrupt changes in seasonal precipitation occur in different years. This requires that the impact of climate change on rainfall (climate change causes rainfall to mutate and become inconsistent time series) and the response of seasonal rainfall to climate change (the abrupt change time are different.) should be fully considered in the analysis of rainfall frequency. Therefore, an inconsistent seasonal rainfall frequency analysis method will be helpful to hydrological

15 management in the context of climate change.

(4) It is found that rainfall in the Chengbi River Basin is affected by the typhoon to a certain extent. It is suggested that the role of typhoons should be fully considered in future rainfall forecasting and other research work. Additionally, we should further analyse the mechanism of how typhoons affect rainfall. This would provide a basis for the management of water resources in the basin.

\section{Conclusions}

In this study, a scientific and rational framework for the analysis of monthly and seasonal rainfall for a typhoon-influenced area in a Chinese karst basin is put forward. First, relative variability, PCD and PCP are used for analysing the inner-annual distribution. Second, trend, abrupt change time and period are studied using the Sen+Mann-Kendall methods, hydrologic variation diagnosis system, and wavelet analysis. Finally, the correlation between summer-autumn rainfall and typhoons is

25 analysed using Pearson correlation coefficient and Grey relational analysis.

Some conclusions are as follows: (1) The monthly rainfall in Chengbi River Basin is uneven; it is most unstable in December, but in June it is more stable than in other months. PCD shows a slight upward trend while PCP is decreasing. (2) Monthly and seasonal rainfalls show an upward or downward trend, but the trends are not very significant. Monthly, spring and summer rainfalls show a downward trend, while autumn and winter rainfall show an upward trend. Additionally, rainfall in

30 Chengbi River Basin is most likely changed during 1980s-1990s. The main periods of rainfall in summer and winter are shorter than those in spring and autumn. (3) The typhoon-caused rain is the main factor that affects the summer-autumn 
Nat. Hazards Earth Syst. Sci. Discuss., https://doi.org/10.5194/nhess-2018-194

Manuscript under review for journal Nat. Hazards Earth Syst. Sci.

Discussion started: 5 September 2018

(c) Author(s) 2018. CC BY 4.0 License.

(c) (i)

rainfall, and the relationship between typhoons and autumn rainfall is generally more significant than that between typhoons and summer rainfall.

\section{Acknowledgements}

The authors are grateful for the support of the National Natural Science Foundation of China (Grant Nos. 51569003, 5 51579059), the National Key Research and Development Program of China under Grant No. 2017YFC1502405andNo.2016YFC0401303, the Guangxi Natural Science Foundation of China (2017GXNSFAA198361), and the Innovation Project of Guangxi Graduate Education (YCSW2017052).

\section{References}

Conrad, V.: The variability of precipitation, Monthly Weather Review, 69, 5-11,1941.

10 Chen, R. Z., He, H.Y., and Cai, M. : Climatic characteristic analysis of landing tropical cyclones in littoral coverage-area of guangxi, Marine Forecasts, 8, 5327-5333,2005.

Chen, C.J.:Response of precipitation in Yumen to climate change in recent 56 years, Journal of Anhui Agricultural Sciences, 37,3656-3659,2009. (In Chinese)

Dong, Y.: Research on distribution characteristics and forecast for tropical cyclone gale in Guangxi, Guangxi Teachers

15 Education University, 2004.(in Chinese)

Gao, S. F., Yi-Lung,Y., and Tsou, I.: Regional rainfall characteristic analysis for the kaoping river basin. Journal of Hydraulic Engineering, 43, 1341-1348, 2012. (in Chinese)

Guerreiro, S. B., Kilsby, C. G., and Serinaldi, F.: Analysis of time variation of rainfall in transnational basins in iberia: abrupt changes or trends?, Int. J. Climatol, 34, 114-133,2014.

20 Gao, R.X., Gao, H.D., Sun, Q.Z., Xu, D.P., and Li, H.L.: Study on annual distribution characteristics of rainfall in mahuangtian catchment of guanling county, Research of Soil \& Water Conservation, 24 ,152-155+161,2017.

Heghinian, S. M.:A shift of the mean level in a sequence of independent normal random variables: a bayesian approach, Technometrics, 19, 503-506, 1997.

He, X.J. and Ding, Z.Y.: Statistical characteristics of Typhoon heavy rainfall in the Beibu Gulf, Guangxi,Journal of 25 meteorological research and application,,2,:31-35+53,2007.(in Chinese)

Iqbal, and M., J. :A probabilistic approach for estimating return period of extreme annual; rainfall in different cities of Punjab, Arabian Journal of Geosciences, 6,2599-2606,2013.

Iwasaki, H.: Increasing trends in heavy rain during the warm season in eastern japan and its relation to moisture variation and topographic convergence, Int. J. Climatol, 35, 2154-2163,2015. 
Nat. Hazards Earth Syst. Sci. Discuss., https://doi.org/10.5194/nhess-2018-194

Manuscript under review for journal Nat. Hazards Earth Syst. Sci.

Discussion started: 5 September 2018

(c) Author(s) 2018. CC BY 4.0 License.
Natural Hazards

and Earth System

Sciences

Discussions

(c) (i)

Irannezhad, M., Marttila, H., Chen, D. L., and Kløve, B.: Century-long variability and trends in daily precipitation characteristics at three finnish stations, Advances in Climate Change Research,7, 54-69,2016.

Kendall, M.G.:Rank Correlation Methods,Griffin, London, UK,1975.

Liu, S.F.: Grey system theory and its application,Beijing, Science Press,2000. (in Chinese)

5 Lei, H. F., Xie, P., Chen, G. C., and Li,J.: Comparison and Analysis on the Performance of Hydrological Time Series Change-point Testing Methods, Water Resources and Power, 25, 36-40,2007. (in Chinese)

Labat, D., Ababou, R., and Mangin, A.: Introduction of wavelet analyses to rainfall/runoffs relationship for a karstic basin: the case of licq - atherey karstic system (France), Ground Water, 39, 605-615, 2010.

LI, C.J., and Yang, J. H.: Analysis on Variation Characteristics and Trends of Precipitation in Gushanchuan, Ground water,

10 34,136-138+151,2012.(in Chinese)

Luković, J., Bajat, B., Blagojević, D., and Kilibarda, M.:Spatial pattern of recent rainfall trends in serbia (19612009),Regional Environmental Change, 14, 1789-1799,2014.

Mann, H.B.: Nonparametric tests against trend. Econometrica, 13,245-259,1945.

Mo, C.X., Ruan,Y. L., R., Lin, Y. T., and Sun, G. K.: A study on monthly and seasonal variation characteristics of rainfall

15 and its future changes, Water Saving Irrigation, 1,52-57,2018.

Peng, Y., Chu, J., Sun, X., Zhou, H., and Zhang, X.:Flood forecasting that considers the impact of hydraulic projects by an improved topmodel model in the wudaogou basin, northeast china,Water Science \& Technology Water Supply, 16,2016.

Sen, P.K.: Estimates of the regression coefficient based on Kendall's tau,Journal of the American Statistical Association ,63,1379-1389,1968.

20 Sun A.J.:Study on the statistical relationship between the relative variability and the precipitation in China ,Journal of meteorology, 1,102-107,1986.(in Chinese)

Storch, H. V.: Misuses of Statistical Analysis in Climate Research. Analysis of Climate Variability, Springer Berlin Heidelberg, 11-26,1995.

Shuang, Z., Zhou, J., Meng, C., Ge, X., and Chen, J.: Study and application of fuzzy support vector machine based on gray

25 correlation analysis to streamflow forecasting, Journal of Hydroelectric Engineering, 34, 1-6,2015. (In Chinese)

Tarhule, A. and Woo, M.: Changes in rainfall characteristics in northern Nigeria, Int. J. Climatol, 18,1261-1271,2015.

Wei, F.Y. :Modern climate statistical diagnosis and prediction technology,Beijing,Meteorology Press, 1999. (in Chinese)

Wang, J. J., Pei, T. F., Gu, W. L., and Liu, J. G.:Non-uniformity index of annual precipitation distribution. Chinese Journal of Ecology, 26,1364-1368,2007. (in Chinese)

30 Wu,L., Liu, X., and Ma,X.Y.: Spatio-temporal evolutions of precipitation in the Yellow River basin of China from 1981 to 2013 ,Water Science \& Technology Water Supply,16,2016. (in Chinese)

Xu, J.H.:Mathematical methods in Modern Geography (Second Edition) ,Beijing,Higher Education Press,2002. (in Chinese) 
Nat. Hazards Earth Syst. Sci. Discuss., https://doi.org/10.5194/nhess-2018-194

Manuscript under review for journal Nat. Hazards Earth Syst. Sci.

Discussion started: 5 September 2018

(c) Author(s) 2018. CC BY 4.0 License.

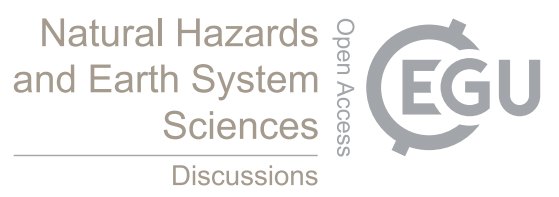

Yu ,S.P., Yang ,J. S., Liu, G.M.,Yao,R.J., and Wang,X.P.: Multiple time scale characteristics of rainfall and its impact on soil salinization in the typical easily salinized area in Huang-Huai-Hai Plain, China, Stochastic Environmental Research and Risk Assessment, 26(7):983-992,2012.

Zhang, L.J., and Qian, Y.F.:Annual distribution feature of precipitation in China and their interannual variations,Acta 5 geographica Sinica, $17,146-163,2003$. (In Chinese)

Zhang, Z. C., Chen, X., Wang, W., and Shi, P.:Analysis of rainfall trend and extreme events in guizhou,Earth \& Environment, 35, 351-356,2007. (In Chinese)

Zhang, Q., Xu, C. Y., Becker, S., Zhang, Z. X., Chen, Y. D., and Coulibaly, M.: Trends and abrupt changes of precipitation maxima in the pearl river basin, china. Atmospheric Science Letters, 10, 132-144,2010.

10 Zhou, Y., Shi, C., Fan, X., and Jun, D. U.: Advances in the research methods of abrupt changes of hydrologic sequences and their applications in drainage basins in china,Progress in Geography, 30, 1361-1369,2011. (In Chinese)

Zeng, S., Zhang, L., Xia, J., and Zhen, Y.: Water cycle characteristic and its responses to climate change of the yongding river basin, Journal of Basic Science \& Engineering, 21, 501-511,2013. (In Chinese)

Zhang, C., Hu, S., and Chen, M.:characteristics of the tropical cyclones influencing Guangxi coastal area,ocean forecast, $1531,37-42,2014$. (In Chinese)

Zhang, Q., Sun, P., and Wang, Y.Q.: Study on climate change and hydrological response in Poyang lake basin, Beijing, China water conservancy and hydropower press, 2015. (In Chinese)

Zou, M. L., Liao, X. P., and Zou, X. H.:Responses of precipitation changes in typical karst area of guangxi to global warming during 1971-2013, Journal of Meteorological Research \& Application, 37,72-75,2016. 